\title{
Intercepted solar radiation by maize crops subjected to different tillage systems and water availability levels
}

\author{
Homero Bergamaschi(1), Genei Antonio Dalmago (2), João Ito Bergonci(3), \\ Cleusa Adriane Menegassi Bianchi Krüger ${ }^{(4)}$, Bruna Maria Machado Heckler ${ }^{(5)}$ and Flavia Comiran ${ }^{(6)}$
}

\begin{abstract}
(1)Universidade Federal do Rio Grande do Sul (UFRGS), Faculdade de Agronomia, Caixa Postal 15100, CEP 91501-970 Porto Alegre, RS, Brazil. E-mail: homerobe@ufrgs.br (2)Embrapa Trigo, Caixa Postal 451, CEP 99001-970, Passo Fundo, RS, Brazil. E-mail: dalmago@cnpt.embrapa.br (3)UFRGS, Departamento de Botânica, CEP 90046-900, Porto Alegre, RS, Brazil. E-mail: joão.bergonci@ufrgs.br (4)Universidade Regional do Noroeste do Estado do Rio Grande do Sul (UNIJUI), Departamento de Estudos Agrários, Rua Comércio, no 3.000, CEP 98700-000, ljuí, Brazil. E-mail: cleusa.bianchi@unijui.edu.br ${ }^{(5)}$ Empresa de Assistência Técnica e Extensão Rural, Alameda Veredinha, s/no, Área Especial, Setor Tradicional, CEP 72720-660 Brazlândia, DF, Brazil. E-mail: bruheckler@hotmail.com ${ }^{(6)}$ Instituto Agronômico do Paraná, BR 376, Km 496, Caixa Postal 129, CEP 84001-970, Ponta Grossa, PR, Brazil. E-mail: fcomiran@iapar.br
\end{abstract}

\begin{abstract}
The objective of this work was to evaluate changes in the photosynthetic photon flux density (PPFD) interception efficiency and PPFD extinction coefficient for maize crop subjected to different soil tillage systems and water availability levels. Crops were subjected to no-tillage and conventional tillage systems combined with full irrigation and non-irrigation treatments. Continuous measurements of transmitted PPFD on the soil surface and incoming PPFD over the canopy were taken throughout the crop cycle. Leaf area index and soil water potential were also measured during the whole period. Considering a mean value over the maize cycle, intercepted PPFD was higher in the conventional tillage than in the no-tillage system. During the initial stages of plants, intercepted PPFD in the conventional tillage was double the PPFD interception in the no-tillage treatment. However, those differences were reduced up to the maximum leaf area index, close to tasseling stage. The lowest interception of PPFD occurred in the conventional tillage during the reproductive period, as leaf senescence progressed. Over the entire crop cycle, the interception of PPFD by the non-irrigated plants was about $20 \%$ lower than by the irrigated plants. The no-tillage system reduced the extinction coefficient for PPFD, which may have allowed a higher penetration of solar radiation into the canopy.
\end{abstract}

Index terms: Zea mays, leaf area, no-tillage, photosynthetic photon flux density, water deficit.

\section{Radiação solar interceptada pela cultura do milho sob diferentes níveis de preparo do solo e disponibilidade hídrica}

Resumo - O objetivo deste trabalho foi avaliar a eficiência da interceptação da radiação fotossinteticamente ativa (RFA) e o coeficiente de extinção da cultura do milho em diferentes sistemas de preparo do solo e níveis de disponibilidade hídrica. O milho foi cultivado em sistemas de plantio direto e preparo convencional combinados a tratamentos de irrigação completa e sem irrigação. Medições contínuas de RFA transmitida à superfície do solo e RFA incidente sobre o dossel foram tomadas ao longo do ciclo da cultura. O índice de área foliar (IAF) e o potencial da água no solo também foram medidos em todo o período. Na média de todo o ciclo da cultura, a RFA interceptada foi maior em preparo convencional do que em plantio direto. Nos estádios iniciais das plantas, a RFA interceptada em preparo convencional foi o dobro daquela em plantio direto. Porém, essas diferenças reduziram-se até o máximo IAF, próximo ao pendoamento. A menor interceptação de RFA pela cultura ocorreu em preparo convencional durante o período reprodutivo, à medida que a senescência foliar progrediu. No ciclo todo, a interceptação de RFA pela cultura não irrigada foi $20 \%$ menor que na irrigada. O sistema plantio direto reduziu o coeficiente de extinção de RFA pelo milho, e proporcionou maior penetração de radiação solar no dossel.

Termos para indexação: Zea mays, área foliar, plantio direto, radiação fotossinteticamente ativa, deficit hídrico.

\section{Introduction}

Plant biomass production depends on the absorption of photosynthetic photon flux density (PPFD) by its leaves and on the efficiency of the plant to convert solar radiation into chemical energy by the photosynthetic process. The amount of absorbed PPFD depends on the efficiency of radiation interception by the canopy, which in turn depends on plant morphology and physiology. An accurate determination of daily intercepted PPFD

Pesq. agropec. bras., Brasília, v.45, n.12, p.1331-1341, dez. 2010 
is often a critical step in crop simulation models which aims at estimating increases in daily biomass and kernel number (Lindquist at al., 2005).

The efficiency of PPFD interception influences the photosynthesis and transpiration processes (Thorpe, 1978). This efficiency depends on the leaf area index (LAI) and on the extinction coefficient, which is related to the canopy structure, especially concerning the shape of the leaf and its inclination (Norman \& Campbell, 1989; Varlet-Grancher et al., 1989; Lindquist et al., 2005). Alterations in the extinction coefficient that shows a constant LAI tend to promote alterations in the intercepted solar radiation, and hence, in the potential accumulation of biomass (Lindquist et al., 2005).

According to Norman \& Campbell (1989), the connection between radiation exchange and canopy structure is so strong that measurements of radiation may be used to infer canopy features, and this relationship becomes the basis for indirect measurement techniques of canopy architecture. A more detailed definition of canopy structure might include the size, shape, orientation and positional distributions of various plant organs, such as leaves and stems. Descriptions of canopy structure are essential to achieve an understanding of plant processes because of the profound influence that structure has on plant-environment interactions (Norman \& Campbell, 1989).

The amount of nutrients in plants, particularly nitrogen, may also affect the efficiency of radiation interception (Dewar, 1996; Scott Green et al., 2003). Additionally, a water deficit may reduce the interception of solar radiation by maize crops due to the rolling up of leaves (Müller \& Bergamaschi, 2005). If the water deficit is prolonged, the number and size of leaves may be reduced. Consequently, the total leaf area may also decrease, thus reducing the interception of solar radiation (Collinson et al., 1999).

The adoption of the no-tillage system has increased rapidly in Brazilian subtropical and tropical agriculture, reducing soil erosion and compaction. Compared to conventional tillage, the no-tillage system generally leads to alterations in the physical properties of the soil and increases in the water available to plants (Dalmago et al., 2009, 2010). Under these conditions, plants may increase their growth rates and leaf area expansion, and in addition the rolling up of leaves may be avoided or delayed.
As a consequence, alterations in the size as well as shape of leaves may change the pattern of interception of solar radiation and, hence, crop yield in different tillage systems. Irrigation may also change the solar radiation interception pattern, since it increases the size and duration of the leaf area by reducing the water deficit.

The objective of this work was to evaluate changes in the PPFD interception efficiency and PPFD extinction coefficient for maize crop subjected to different soil tillage systems and water availability levels.

\section{Materials and Methods}

Data were taken from field experiments carried out during the cropping seasons of 2001/2002 and 2002/2003 at the Agronomic Experimental Station of the Universidade Federal do Rio Grande do Sul, in Eldorado do Sul, Rio Grande do Sul State, Brazil $\left(30^{\circ} 05^{\prime} \mathrm{S} ; 51^{\circ} 39^{\prime} \mathrm{W}, 40-\mathrm{m}\right.$ altitude).

The soil of the experimental area is a Paleudult. The regional climate is a humid subtropical Cfa type, according to Köppen classification, which is the prevailing climate in Southeastern South America. The annual mean precipitation is $1,440 \mathrm{~mm}$. An average of $425 \mathrm{~mm}$ falls from November to February, comprising the experimental period. Mean air temperature ranges from $21.1^{\circ} \mathrm{C}$ (November) to $24.6^{\circ} \mathrm{C}$ (January), while mean soil temperature, at a depth of $5 \mathrm{~cm}$, ranges from $22.3^{\circ} \mathrm{C}$ (November) to $27.1^{\circ} \mathrm{C}$ (January). Maximum global solar radiation occurs in December, with a mean of $26 \mathrm{MJ} \mathrm{m}^{-2}$ day $^{-1}$ (Bergamaschi et al., 2003).

A four-block bifactorial experimental design was used, distributed over a 0.5 -ha area. The main factor (soil tillage) comprised two systems, which had been applied since 1995: no-tillage (NT) and conventional tillage (CT). Two levels of irrigation were combined with the tillage systems: full irrigation (I) and no-irrigation (NI).

The two soil tillage treatments were applied to a mixture of Avena strigosa and Vicia sativa, cultivated every winter. For the no-tillage system, the winter mixture was dried with herbicide (glyphosate), and straws were laid down on the soil surface. In the conventional tillage system, green biomass was incorporated into the soil by plowing at a depth of $0.18 \mathrm{~m}$ to $0.25 \mathrm{~m}$. After plowing, the soil received two superficial operations with a disc-harrow, one of 
them on the same day and another one, just before sowing.

Irrigation was applied through a line of sprinklers spaced $6 \mathrm{~m}$ apart. The sprinklers were installed in the central row of the experiment as the longitudinal section. Thus, the full irrigation treatment (I) was applied close to the sprinkler line, and a non-irrigated level (NI) was maintained along the lateral strips according to Hanks et al. (1980). The irrigation management was based on the soil water potential, which was measured by mercury tensiometers at depths of 15, 30, 45 and $60 \mathrm{~cm}$ in the non-irrigated and no-tilled plots. Soil water potential was measured in all plots at the same depths using mercury tensiometers. The amount of each water application was quantified through a weighing lysimeter installed in the middle of a uniform area, located close to the experiment and which had been cropped under equal irrigated treatment conditions.

Measurements from the tensiometers were taken in all treatments, daily and on three-day intervals. Soil-water matrix potential $\left(\Psi_{\mathrm{m}}\right)$ was calculated by:

$\Psi_{\mathrm{m}}=\left(-12.6 \mathrm{H}+\mathrm{h}_{\mathrm{c}}+\mathrm{z}\right) 0.0001$

where $\Psi_{\mathrm{m}}(\mathrm{MPa})$ is the soil-water matrix potential, $\mathrm{H}$ $(\mathrm{cm})$ is the height of the mercury column above the cube, $h_{c}(\mathrm{~cm})$ is the vertical distance from the soil surface to the mercury level in the cube, and $\mathrm{z}(\mathrm{cm})$ is the vertical distance from the soil surface to the center of the porous capsule of each tensiometer. The constant 0.0001 converts $\Psi_{\mathrm{m}}$ from $\mathrm{cm}$ of $\mathrm{H}_{2} \mathrm{O}$ to $\mathrm{MPa}$.

A short-season maize hybrid (Pioneer 32R21) was sown on November 16, 2001 and November 25, 2002. The crop arrangement comprised a row spacing of $0.75 \mathrm{~m}$ and a population of 65,000 plants per hectare. In the first year, soil fertilization consisted of $125-125-145 \mathrm{~kg} \mathrm{ha}^{-1}$ of $\mathrm{P}_{2} \mathrm{O}_{5}, \mathrm{~K}_{2} \mathrm{O}$, and $\mathrm{N}$, respectively. In the second year, it comprised 100-100-145 $\mathrm{kg} \mathrm{ha}^{-1}$ of $\mathrm{P}_{2} \mathrm{O}_{5}, \mathrm{~K}_{2} \mathrm{O}_{5}$, and $\mathrm{N}$, respectively. The nitrogen was applied in three doses: in the first dose, $25 \mathrm{~kg} \mathrm{ha}^{-1}$ of $\mathrm{N}$ was applied together with the phosphorus and potassium fertilizers in the sowing operation; two subsequent fertilizations of $60 \mathrm{~kg} \mathrm{ha}^{-1}$ of $\mathrm{N}$ were applied when the plants had fully expanded to four and eight leaves, respectively. The crop was maintained without weed competition by means of applying herbicides, according to official recommendations for maize.

The photosynthetic photon flux density (PPFD) was measured from the beginning of plant growth to physiological maturity in all treatments. The incoming PPFD ( PPFD $_{\text {inc }}$ ) was measured through a quantum sensor LI-COR, model LI190SB(LI-COR Inc., Lincoln, NE, USA) installed above the crop. The transmitted PPFD $\left(\right.$ PPFD $\left._{\mathrm{t}}\right)$ was measured $0.05 \mathrm{~m}$ above soil surface, using four sets of sensors (four replications), each comprehending five photovoltaic cells. The sets of sensors were calibrated in open sky, before and after each experiment, using a quantum sensor LI-COR, model LI190SB (LI-COR Inc., Lincoln, NE, USA) as a reference. They were also evaluated in terms of response time so they would have a similar performance in the set. The sensors were connected to a multiplexer and were monitored through a Campbell CR10 datalogger (Campbell Scientific do Brasil, São Paulo, SP, Brazil). Measurements were taken each $30 \mathrm{~s}$, while the mean values were stored independently every $15 \mathrm{~min}$. The intercepted PPFD $\left(\right.$ PPFD $\left._{\text {int }}\right)$ was calculated for each 15-min period by the equation:

PPFD $_{\text {int }}=$ PPFD $_{\text {inc }}-$ PPFD $_{\mathrm{t}}$

With the mean value of $P_{P F D_{\text {int }}}$ for each 15-min period (equation 2), the daily mean value of $\mathrm{PPFD}_{\text {int }}$ was calculated for each treatment in four replications.

During the first experiment (2001/2002), leaf area index (LAI) was determined using weekly measurements taken from four plants per treatment, which were located in a continuous portion of the central rows of plots (not randomly). The leaf area was measured by an electronic planimeter LI-COR, model LI 3000 (LI-COR Inc., Lincoln, NE, USA). By means of data from the first cropping season (2001/2002), regression equations were adjusted for each tillage system and irrigation level to estimate LAI according to degree-days. Thus, in the second experiment (2002/2003), LAI was estimated using the adjusted equations for the same hybrid and treatments. The best adjustment was obtained using the following model:

$\mathrm{LAI}=\mathrm{a} /\left\{1+\exp \left[-\left(\mathrm{x}-\mathrm{x}_{\mathrm{o}}\right) / \mathrm{b}\right]\right\}$

in which $\mathrm{a}, \mathrm{b}$ and $\mathrm{x}_{\mathrm{o}}$ are coefficients of the equations, and $\mathrm{x}$ is degree-days. Degree-days were calculated from the daily mean air temperature measured at an automatic Weather Watch 2000 station (Campbell Scientific do Brasil, São Paulo, SP, Brazil), located close to the experimental area. A minimum base temperature of $8^{\circ} \mathrm{C}$ was considered (Kiniry, 1991). Plant height was measured at seven-day intervals, in all treatments and cropping seasons. 
Daily measurements of rainfall and meteorological data, for calculating the reference evapotranspiration (ETo) (Penman, 1948), were collected at the same automatic weather station.

The efficiency of PPFD interception $\left(\varepsilon_{\text {int }}\right)$ was estimated as the ratio between $\mathrm{PPFD}_{\text {int }}$ (equation 2) and the total $P P F D_{\text {inc }}$ by the equation:

$\varepsilon_{\text {int }}=\mathrm{PPFD}_{\text {int }} / \mathrm{PPFD}_{\text {inc }}$

For each soil management and water availability treatment, $\varepsilon_{\text {int }}$ was related to the daily values of LAI to estimate the extinction coefficient (k) of the canopy. Estimated $\mathrm{k}$ derived by manipulating the Monsi \& Saeki (1953) equation, as following:

$\operatorname{Ln}\left(1-\varepsilon_{\text {int }}\right)=-$ b LAI

Regression analyses at a level of 5\% probability were used to evaluate LAI and PPFD, as well as the respective coefficients.

The grain yield ( $\mathrm{kg} \mathrm{ha}^{-1}, 13 \%$ of moisture) was determined at the end of each experiment. Two ten-meter-long segments on the two central plant rows were harvested in all the plots. Data were submitted to variance analyses, and mean values were compared by the Tukey test at a level of $5 \%$ probability of error.

\section{Results and Discussion}

The rainfall and the reference evapotranspiration (ETo) during the experimental period were approximately $18 \%$ higher and $6 \%$ lower, respectively, than the climatologic means in the region. However, they showed significant variations throughout the two cropping seasons (Figure 1). The ETo remained close to the climatology at the beginning of the crop cycle (establishment of crop stand), but it surpassed the climatologic values during the vegetative and flowering stages. From the beginning of the crop cycle until 30 days after plant emergence (30 DAE), rainfall amounts were $35 \%$ and $74 \%$ higher than the climatologic means in 2001/2002 and 2002/2003, respectively. However, they were lower than the climatologic means during the rest of the vegetative period, particularly from $45 \mathrm{DAE}$ to $60 \mathrm{DAE}$ in $2001 / 2002$ and 55 DAE to 70 DAE in 2002/2003. Low rainfall amounts and high evaporative demand occurred from tasseling to the beginning of grain filling during the second cropping season (2002/2003). These conditions allow a short period of drought stress in plants, when the water demand is at its maximum in maize crops.

The soil water potential $\left(\Psi_{\mathrm{m}}\right)$ tended to be mostly higher in the no-tilled plots than in the conventional tillage (Figure 2). This tendency was verified in all cases (days and soil depths), pointing to a higher water availability of plants in the untilled soil than in the tilled soil. Working in the same experiment, Bianchi et al. (2005) observed higher leaf water potential in no-tillage than in conventional tillage during the cropping season 2002/2003.

Differences in $\Psi_{\mathrm{m}}$ among the soil tillage treatments tended to increase as the soil became drier throughout the crop cycle, mainly in high evaporative demand (Figure 2). Differences among $\Psi_{\mathrm{m}}$ values tended to be lower in the irrigated plots than in the non-irrigated treatments, indicating that water applications may reduce the effects of the tillage system on crop growth and production. The capacity of the soil to hold water available for plants is lower under conventional tillage

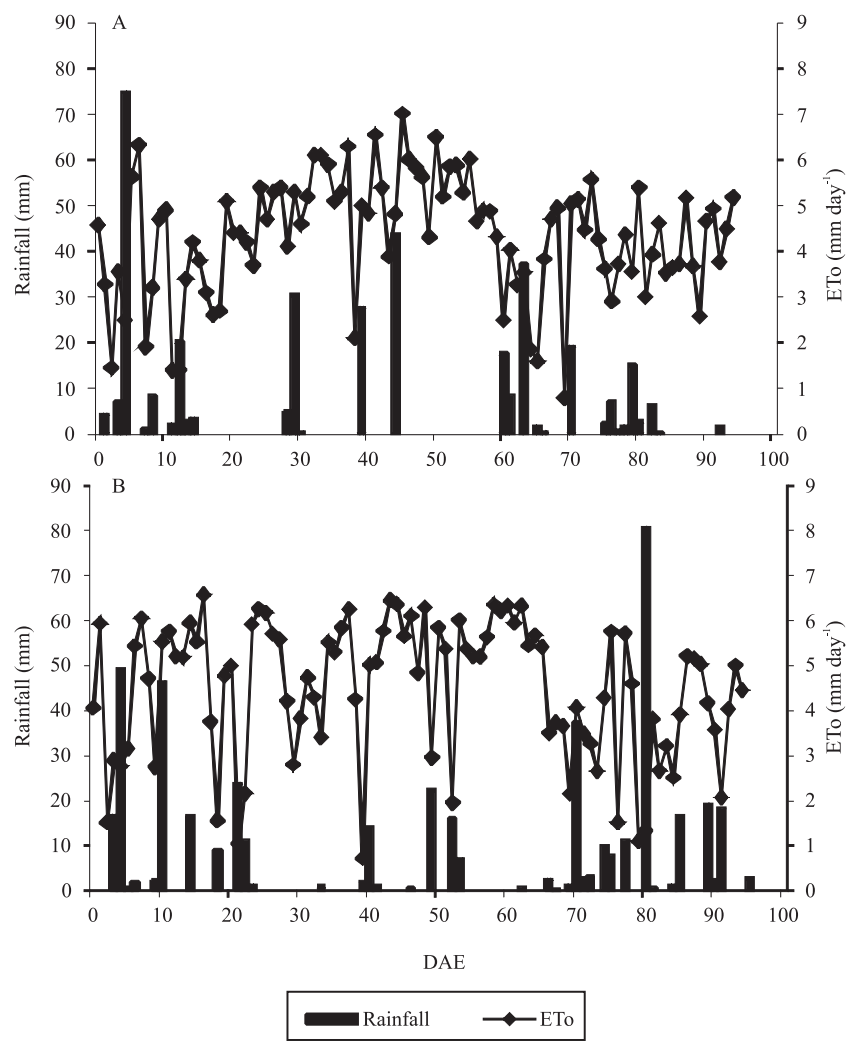

Figure 1. Rainfall and reference evapotranspiration (ETo) as function of days after the emergence (DAE) of maize plants, during the 2001/2002 (A) and 2002/2003 (B) cropping seasons. Eldorado do Sul, Brazil. 
than under no-tillage system, as observed by Dalmago et al. (2009). However, differences in the availability of soil water may be attributed mostly to differences in weather conditions when comparing the two cropping seasons (Figure 1).

Leaf area index and plant height had a similar time-evolution in, no-tillage and conventional tillage, as well as water conditions in both experiments (Figure 3). Significant differences between treatments were observed around LAI $4 \mathrm{~m}^{2} \mathrm{~m}^{-2}$ and after (40 DAE), when low rainfalls and high evaporative demand (ETo) occurred in both cropping seasons (Figure 1). This may explain the reductions of about $20 \%$ of LAI in the non-irrigated plots in comparison with the maximum LAI observed in the irrigated areas in both experiments. The irrigated plots tended to have higher values of LAI and plant height in the untilled plots than in the conventional tillage, which is in accordance with the highest water availability in the untilled soil (Figure 2), as observed by Dalmago et al. (2009).

The intercepted PPFD had similar trends in all treatments (Figure 4). The intercepted PPFD followed the evolution of the leaf area index, increasing up to the maximum LAI, which ranged from 4.5 to $5.0 \mathrm{~m}^{2} \mathrm{~m}^{-2}$, at around 60 DAE (Figure 3). Sivakumar \& Virmani (1984) obtained similar results concerning maize and sorghum when analyzing the percentage of intercepted PPFD according to the leaf area index.

After attaining the maximum LAI, the canopy tended to maintain a high ratio between the intercepted and incoming PPFD (Figure 4). However, variations in PPFD interception occurred. These variations should be attributed to changes of incoming PPFD $_{\text {inc }}$ due to cloudiness, particularly during rainy periods (Figure 1). These variations occurred in both cropping seasons, even at the beginning of the growing period. In addition
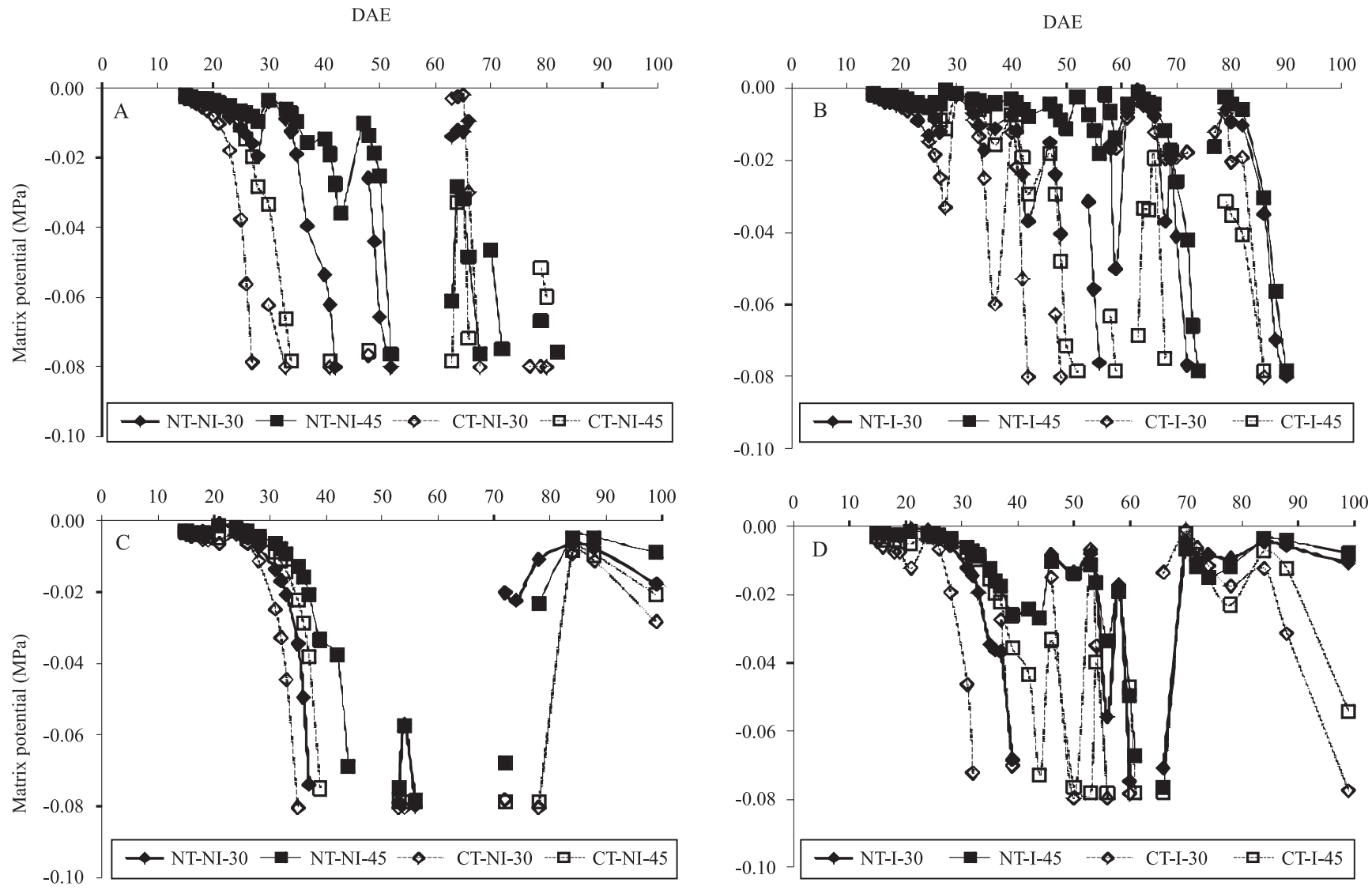

Figure 2. Matrix water potential in the soil at 30 and $45 \mathrm{~cm}$ deep, in no-tillage (NT) and conventional tillage (CT) systems, and in irrigated (I) and non-irrigated (NI) treatments, as function of days after the plant emergence (DAE) of maize plants, during the 2001/2002 (A, B) and 2002/2003 (C, D) cropping seasons. 

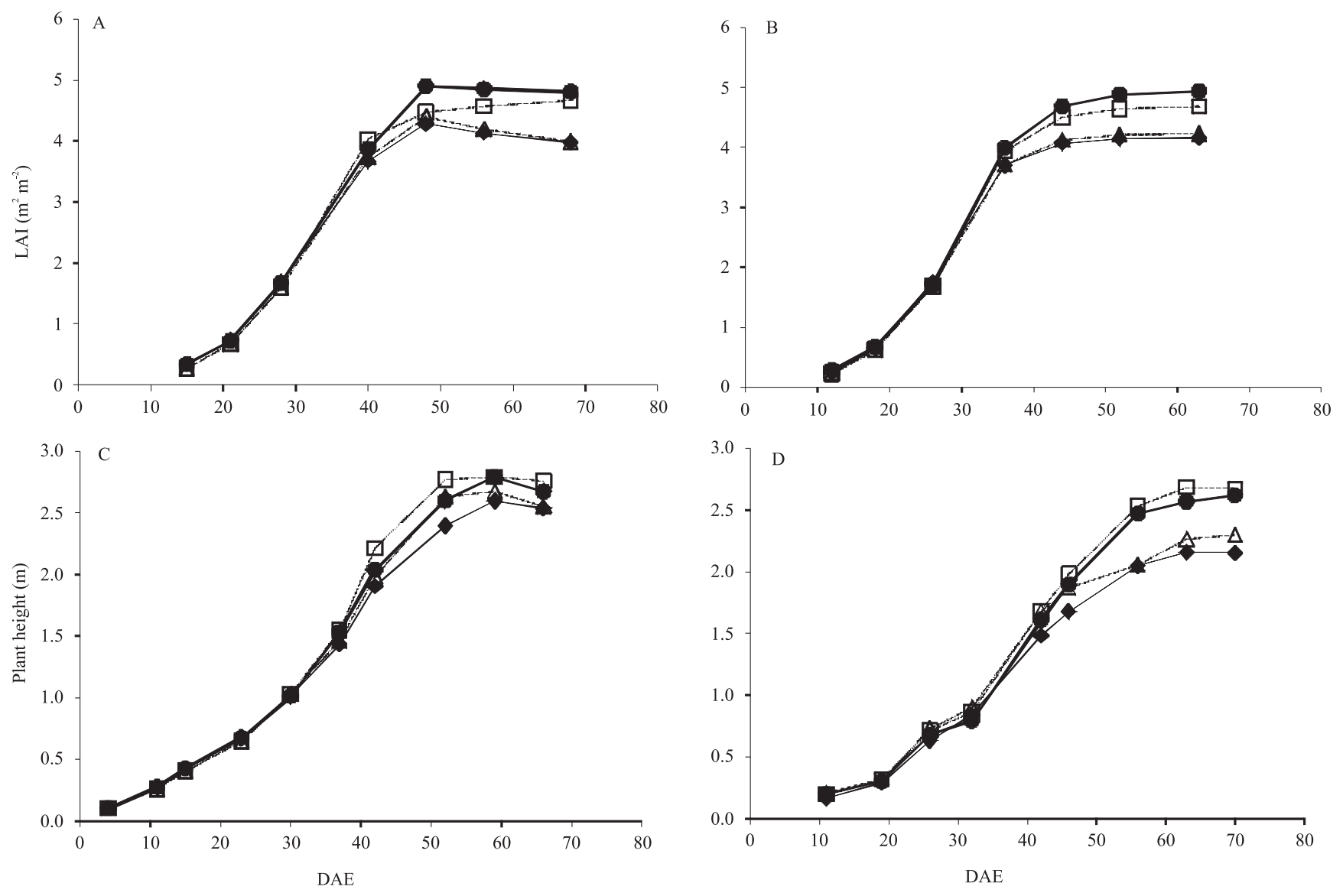

$$
\longrightarrow \text { NT(I) } \quad \cdots-\square-\text { - CT(I) — }
$$

Figure 3. Leaf area index (LAI) measured in 2001/2002 (A) and estimated in 2002/2003 (B); measured plant height in $2001 / 2002$ (C) and in 2002/2003 (D) as function of days after the plant emergence (DAE) of irrigated (I) and non-irrigated (NI) maize crops subject to no-tillage (NT) and conventional soil tillage (CT).

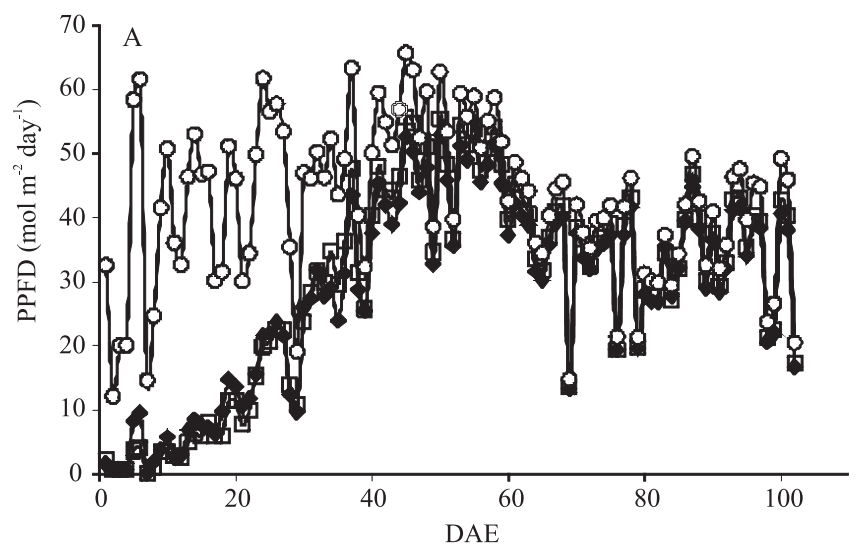

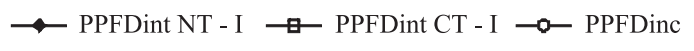

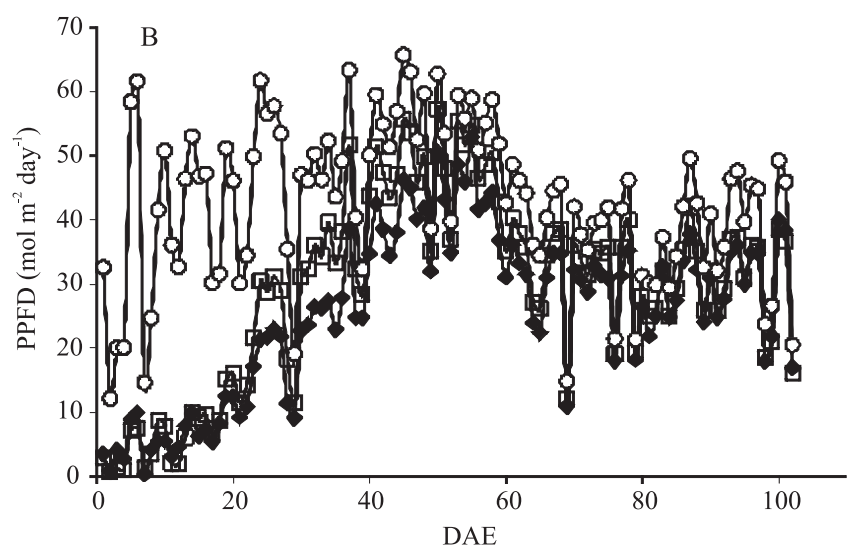

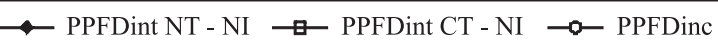

Figure 4. Incoming photosynthetic photon flux density $\left(\mathrm{PPFD}_{\text {inc }}\right)$ and intercepted photosynthetic photon flux density $\left(\mathrm{PPFD}_{\text {int }}\right)$ as function of days after the plant emergence (DAE) in maize cropped in no-tillage (NT) and conventional soil tillage (CT), irrigated (I) - A and non-irrigated (NI) - B, as an average of the 2001/2002 and 2002/2003 cropping seasons. 
to weather conditions, a natural reduction of incoming solar radiation is expected to happen after the middle of the summer season, as a consequence of the solar declination. Decreases in intercepted PPFD may also be expected in maize crops during the grain-filling period due to leaf senescence (Maddoni \& Otegui, 1996; Collinson et al., 1999; Lindquist et al., 2005).

The interception of PPFD was higher in the conventional tillage than in the no-tillage system, particularly during the vegetative stages (Figure 4). The efficiency of PPFD interception emphasizes the differences among treatments (Figure 5). These differences were quite clear in both irrigation treatments through 2002/2003 cropping season, when a drought period occurred during the maximum plant growth rate from 25 to $40 \mathrm{DAE}$ (Figure 1). First season data (2001/2002) showed a similar tendency, but the differences between the tillage systems were reduced in the irrigated plots. Past reaching the maximum LAI, after tasseling stage, the differences in PPFD $_{\text {int }}$ between the two tillage systems tended to become smaller than in the vegetative period.
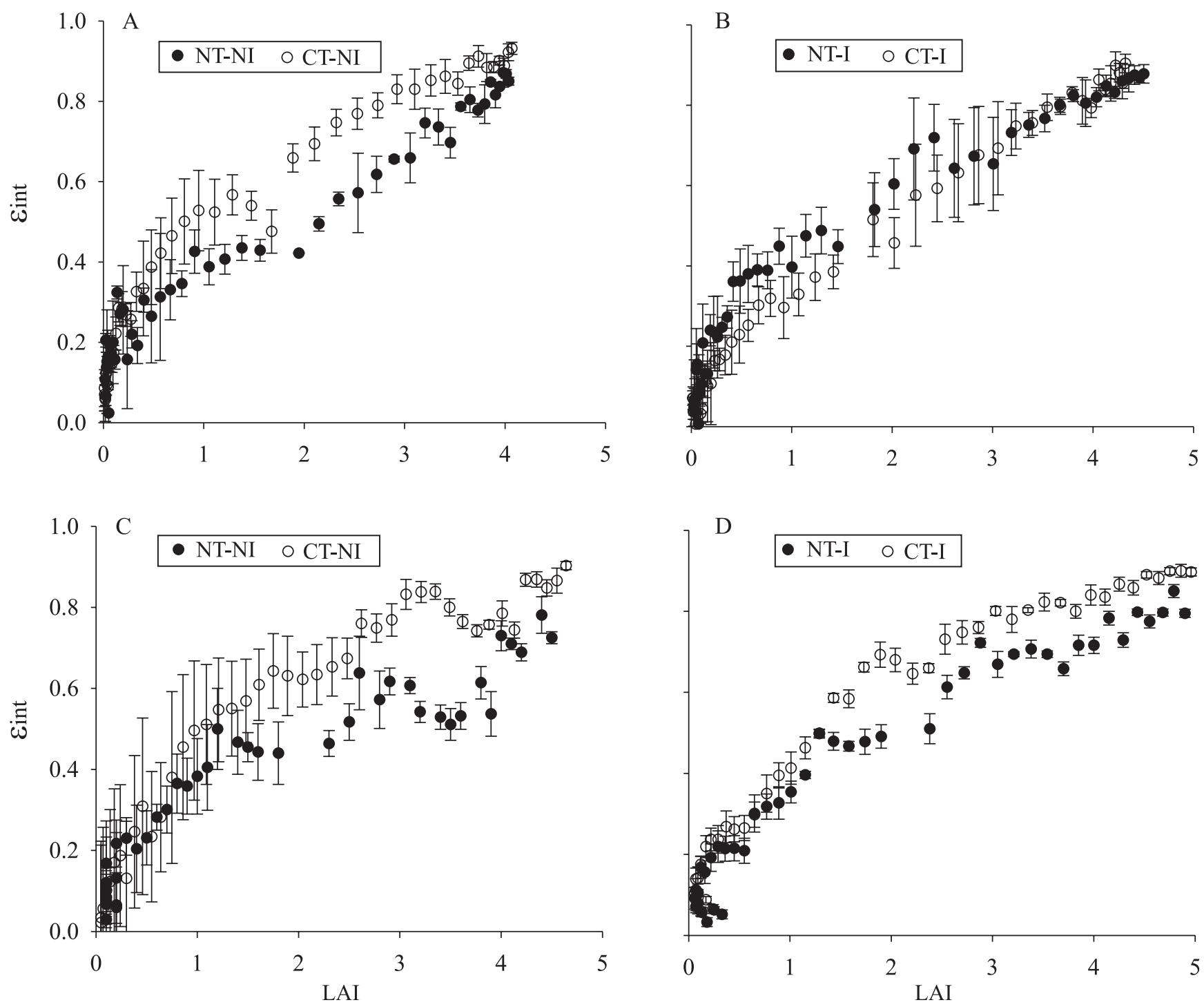

Figure 5. Efficiency of PPFD interception $\left(\varepsilon_{\text {int }}\right)$ as function of the leaf area index (LAI) in maize crops subject to no-tillage (NT) and conventional soil tillage (CT), irrigated (I) and non-irrigated (NI), in the 2001/2002 (A, B) and 2002/2003 (C, D) cropping seasons. 
During the 2002/2003 cropping season, the interception of PPFD by the maize canopy was more than twice as high in the conventional tillage than in the no-tillage system, since plant emergence to 25 days after emergence. This tendency may lead to differences in the canopy structure between the treatments due to alterations in leaf size and shape. This hypothesis was considered when plants were observed in the field during both cropping seasons, since leaves appeared to be shorter, revealing a more vertical position, in the untilled plots than in the conventional tillage. According to Norman \& Campbell (1989), indirect methods involving measurements of radiation may be used to infer about the canopy structure. Actually, Maddoni \& Otegui (1996) observed variations in leaf inclination among different maize genotypes, which were related to alterations in the pattern of PPFD interception. Generally, mineralization of the organic matter in tilled soils is faster than in untilled soils early in the crop cycle (Bayer et al., 2006). This rapid mineralization may increase the availability of nitrogen to plants, thereby affecting the leaf growth and architecture. Concerning PPFD distribution in the canopy, Dreccer et al. (2000) observed a direct relationship between LAI and the $\mathrm{N}$ content in leaves, allowing increases in intercepted radiation by leaves with high $\mathrm{N}$ content.

Differences in $\mathrm{PPFD}_{\text {int }}$ among the irrigated plots were lower than the differences among the non-irrigated plots for both cropping seasons (Figure 5). Furthermore, the effect of the irrigation level tended to increase as the water deficit progressed in the non-irrigated plots. This increase was verified due to increments in the crop water demand around the maximum LAI (Figure 2) combined with reduced rainfall (Figure 1). This tendency was clear during the second cropping season (2002/2003), when water deficits enhanced the interaction of the treatments. Oscillations in the efficiency of PPFD interception in the non-irrigated plots, as a consequence of water deficits, were observed in both cropping seasons (Figure 5). In general, higher oscillations were verified in the conventional tillage system, where the water deficit was stronger than in untilled plots.

During the second cropping season, the maximum efficiency of PPFD interception for the maize cropped in conventional tillage was close to 0.9 in both the irrigated and non-irrigated plots (Figure 5). Meanwhile, these respective irrigation treatments allowed a maximum efficiency in PPFD interception of about 0.8 and 0.7 in the no-tillage system. In the first cropping season, the maximum LAI showed little difference between the irrigated and non-irrigated treatments, which can be attributed to the rainy conditions (Figure 1). However, differences among the tillage systems in the non-irrigated plots had the same tendency as the second season, i.e., higher intercepted PPFD under no-tillage than in conventional tillage for the entire crop cycle. Therefore, maize populations cropped in no-tilled areas may have an equivalent PPFD interception even with a higher LAI than in the conventional tillage.

Conventional tillage system tended to promote a higher efficiency of PPFD interception than the no-tillage system concerning similar values of LAI (Figure 5), which suggests that the tillage systems may cause alterations in leaf architecture, according to Norman \& Campbell (1989). This aspect may explain higher values of maximum LAI in the untilled than in the tilled areas. Working with several maize hybrids, Maddoni \& Otegui (1996) also observed variations in the efficiency of energy interception for similar values of LAI, which were attributed to differences in the angle of leaf inclination. However, during a very dry season, Kunz et al. (2007) were unable to describe a clear tendency for maize leaf angles among untilled and tilled plots.

Regression coefficients of each model in Figure 6 represent the extinction coefficients of PPFD in the canopy for each treatment. Statistical analyses revealed that the extinction coefficients were lower under no-tillage than in conventional tillage, with higher differences in non-irrigated than in irrigated plots (Table 1). During a very dry season, Kunz et al. (2007) observed an opposite tendency among the same tillage systems, either for irrigated or non-irrigated plots, regardless of plant arrangements.

The extinction coefficients for PPFD ranged from 0.28 to 0.43 in the no-tillage system, and the highest values occurred in the 2001/2002 cropping season, which were statistically different from those observed in the 2002/2003 season (Table 1). A similar pattern was verified in the conventional system, which had coefficients ranging from 0.41 to 0.58 . All observed values are higher than those cited in the literature for maize cropped under different conditions (Gosse et al., 1986; Müller \& Bergamaschi, 2005), but they are similar to those observed by Kunz (2007) on the same maize hybrid. Variations among extinction 
coefficients in maize crops may be attributed to differences in size, pattern of distribution and inclination angle of leaves of modern hybrids. There can also be differences in management practices, particularly the plant arrangement, as was observed by Maddoni \& Otegui (1996).
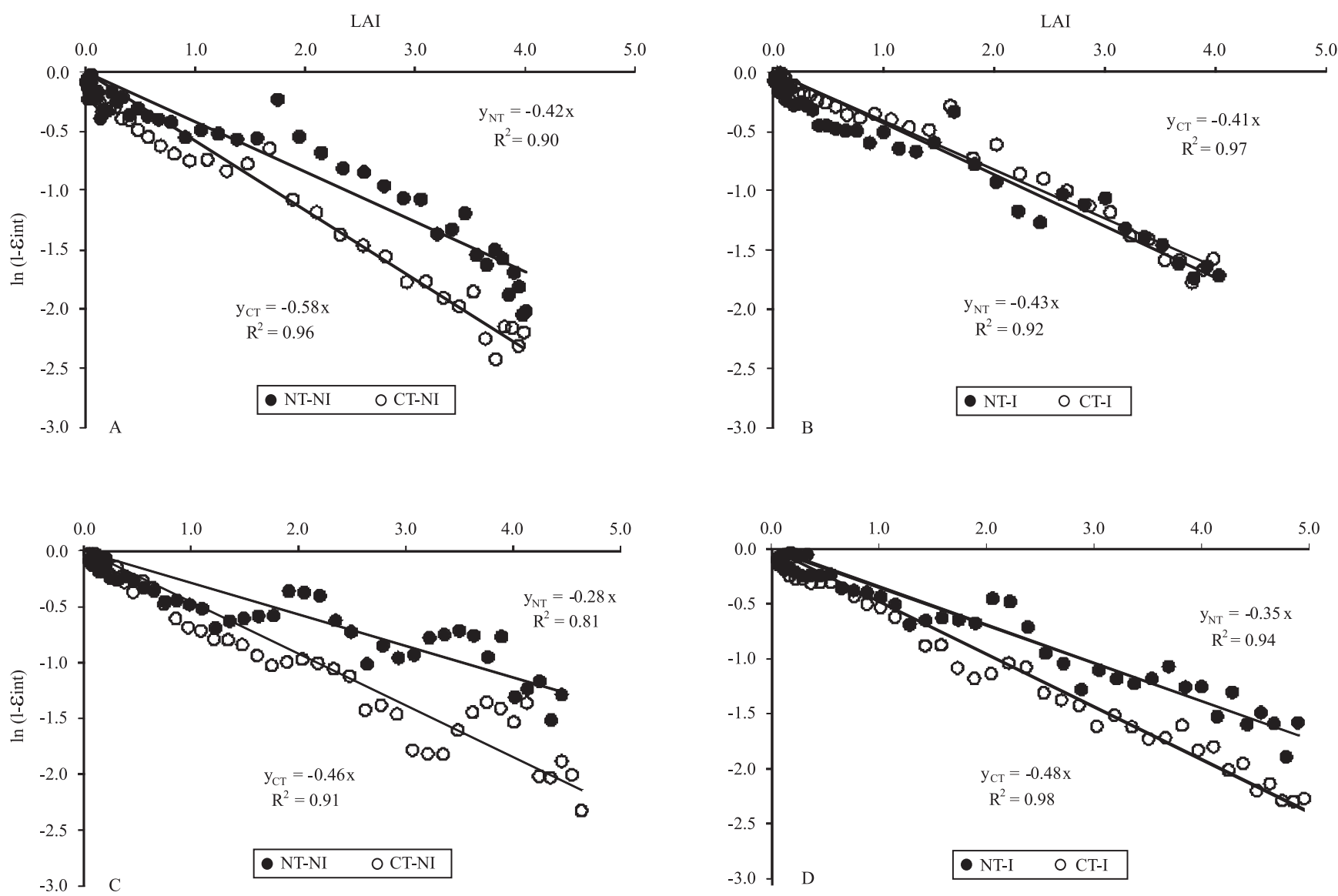

Figure 6. Relationships between $\ln \left(1-\varepsilon_{\text {int }}\right)$ and leaf area index (LAI) in maize crops subject to no-tillage (NT) and conventional soil tillage (CT), irrigated (I) and non-irrigated (NI), in 2001/2002 (A, B) and 2002/2003 (C, D) cropping seasons; $\varepsilon_{\text {int }}$ is the efficiency of PPFD interception.

Table 1. Extinction coefficient for photosynthetic photon flux density (PPFD) in maize crops in no-tillage and conventional tillage, irrigated and non-irrigated, in the 2001/2002 e 2002/2003 cropping seasons ${ }^{(1)}$.

\begin{tabular}{|c|c|c|c|c|}
\hline \multirow[t]{2}{*}{ Treatments } & \multicolumn{2}{|c|}{$2001 / 2002$} & \multicolumn{2}{|c|}{$2002 / 2003$} \\
\hline & Irrigated & Non irrigated & Irrigated & Non irrigated \\
\hline & \multicolumn{4}{|c|}{ Extinction coefficient } \\
\hline No-tillage & $0.43 \mathrm{aA}$ & $0.42 \mathrm{bA}$ & $0.35 \mathrm{bB}$ & $0.28 \mathrm{bC}$ \\
\hline Conventional tillage & $0.41 \mathrm{aC}$ & $0.58 \mathrm{aA}$ & $0,48 \mathrm{aB}$ & $0.46 \mathrm{aB}$ \\
\hline \multirow[t]{2}{*}{ CV (\%) } & & & & \\
\hline & \multicolumn{4}{|c|}{ Grain yield $\left(\mathrm{kg} \mathrm{ha}^{-1}\right)$} \\
\hline No-tillage & $8.827 \mathrm{aA}$ & $7.014 \mathrm{aB}$ & $8.064 \mathrm{bA}$ & $1.355 \mathrm{aB}$ \\
\hline Conventional tillage & $9.583 \mathrm{aA}$ & $5.953 \mathrm{aB}$ & $9.596 \mathrm{aA}$ & $1.451 \mathrm{aB}$ \\
\hline $\mathrm{CV}(\%)$ & & & & \\
\hline
\end{tabular}


The observed water deficit increases differences in the extinction coefficients between the tillage systems. At the same time, it promoted a higher oscillation of coefficients in the non-irrigated than in the irrigated plots (Figure 6). The increasing variability under water stress can be attributed to the rolling up of leaves when the plants experienced a shortage of water in the soil, particularly when combined with high transpiration demand. Therefore, water deficit increases the transmission of PPFD to the soil surface, as observed by Müller \& Bergamaschi (2005).

Varlet-Grancher et al. (1989) and Scott Green et al. (2003) reported a similar tendency when relating the angle of leaf inclination to the extinction coefficient. This tendency may allow for, hypothetically, the convenience of increasing the plant population or reducing the row spacing in maize cropped in a no-tillage system, particularly if using irrigation, in order to compensate for reductions of the extinction coefficient for PPFD.

Although the efficiency of PPFD interception was higher in the conventional tillage than in the no-tillage system, there were no significant differences in grain yield, except for the fully-irrigated level in the second cropping season - 2002/2003 (Table 1). Grain yields were significantly different only on the levels of irrigation in the tillage system. This difference may be attributed to the occurrence of water deficits in the critical stages of the crop, particularly during the second season (Figure 1). The water deficit from the flowering stage to the beginning of grain-filling in the 2002/2003 season, as analyzed by Bergamaschi et al. (2004), reduced grain yield at a rate around $85 \%$, irrespective of the tillage system. In addition, since the irrigation was managed according to the soil water potential of the fully irrigated level in the untilled plots, plants in the conventional tillage system may have experienced some water deficits for short periods, as observed by Bianchi et al. (2005). These aspects may explain the weak relations between the observed grain yields and the efficiency of PPFD interception.

\section{Conclusions}

1. The interception of photosynthetic photon flux density by maize canopies may vary among soil tillage systems, on similar leaf area indexes.
2. Water deficit reduces the interception of photosynthetic photon flux density by maize crops, irrespective of the tillage system.

3. Water deficit in maize plants promotes a higher variability in intercepted photosynthetic photon flux density under conventional tillage than under no-tillage system.

4. The efficiency of photosynthetic photon flux density interception and the extinction coefficient for PPFD are usually higher in maize cropped in the conventional tillage than in the no-tillage system.

\section{References}

BAYER, C.; LOVATO, T.; DIECKOW, J.; ZANATTA, J.A.; MIELNICZUK, J. A method for estimating coefficients of soil organic matter dynamics based on long-term experiments. Soil and Tillage Research, v.91, p.217-226, 2006.

BERGAMASCHI, H.; DALMAGO, G.A.; BERGONCI, J.I.; BIANCHI, C.A.M.; MÜLLER, A.G.; COMIRAN, F.; HECKLER, B.M.M. Distribuição hídrica no período crítico do milho e produção de grãos. Pesquisa Agropecuária Brasileira, v.39, p.831-839, 2004.

BERGAMASCHI, H.; GUADAGNIN, M.R.; CARDOSO, L.S.; SILVA, M.I.G. da. Clima da Estação Experimental da UFRGS e região de abrangência. Porto Alegre: UFRGS, 2003. 77p.

BIANCHI, C.A.M.; BERGONCI, J.I.; BERGAMASCI, H.; DALMAGO, G.A. Ajuste osmótico em milho, cultivado em diferentes sistemas de manejo de solo e disponibilidade hídrica. Pesquisa Agropecuária Brasileira, v.40, p.645-651, 2005.

COLLINSON, S.T.; BERCHIE, J.; AZAM-ALI, S.N. The effect of soil moisture on light interception and the conversion coefficient for three landraces of bambara groundnut (Vigna subterranea). Journal of Agricultural Science, v.133, p.151-157, 1999.

DALMAGO, G.A.; BERGAMASCHI, H.; BERGONCI, J.I.; KRÜGER, C.A.M.B.; COMIRAN, F.; HECKLER, B.M.M. Retenção e diponibilidade de água às plantas, em solos sob plantio direto e preparo convencional. Revista Brasileira de Engenharia Agrícola e Ambiental, v.13, p.855-864, 2009.

DALMAGO, G.A.; BERGAMASCHI, H.; KRÜGER, C.A.M.B.; BERGONCI, J.I.; COMIRAN, F.; HECKLER, B.M.M. Evaporação da água na superfície do solo em sistemas de plantio direto e preparo convencional. Pesquisa Agropecuária Brasileira, v.45, p.780-790, 2010

DEWAR, R.C. The correlation between plant growth and intercepted radiation: an interpretation in terms of optimal plant nitrogen content. Annals of Botany, v.78, p.125-136, 1996.

DRECCER, M.F.; SCHAPENDONK, H.C.M.; VAN OIJEN, M.; POT, C.S.; RABBINGE, R. Radiation and nitrogen use at the leaf and canopy level by wheat and oilseed rape during the critical period for grain number definition. Australian Journal of Plant Physiology, v.27, p.899-910, 2000. 
GOSSE, G.; VARLET-GRANCHER, C.; BONHOMME, R.; CHARTIER, M.; ALLIRAND, J.-M.; LEMAIRE, G. Production maximale de matière sèche et rayonnement solaire intercepté par un couvert végétal. Agronomie, v.6, p.47-56, 1986.

HANKS, R.J.; SISSON, D.V.; HURST, R.L.; HUBBARD, K.G. Statistical analysis of results from irrigation experiments using the line-source sprinkler system. Soil Science Society of America Journal, v.44, p.886-888, 1980.

KINIRY, J.R. Maize physics development. In: HANKS, J.; RITCHIE, J.T. (Ed.). Modeling plant and soil systems. Madison: ASA/CSSA/SSSA, 1991. p.55-57. (ASA/CSSA/SSSA. Agronomy monograph, 31).

KUNZ, J. H.; BERGONCI, J.I.; BERGAMASCHI, H.; DALMAGO, G.A.; HECKLER, B.M.M.; COMIRAN, F. Uso da radiação solar pelo milho sob diferentes preparos do solo, espaçamento e disponibilidade hídrica. Pesquisa Agropecuária Brasileira, v.42, p.1511-1520, 2007.

LINDQUIST, J.L.; ARKEBAUER, T.J.; WALTERS, D.T.; KENNETH, G.C.; DOBERMANN, A. Maize radiation use efficiency under optimal growth conditions. Agronomy Journal, v.97, p.72-78, 2005.

MADDONI, G.A.; OTEGUI, M.E. Leaf area, light interception, and crop development in maize. Field Crops Research, v.48, p.81-87, 1996.

MONSI, M.; SAEKI, T. The light factor in plant communities and its significance for dry matter production. Japanese Journal of Botany, v.14, p.22-52, 1953.
MÜLLER, A.G.; BERGAMASCHI, H. Efficiency of interception, absorption, and photosynthetically active radiation use in maize crops (Zea mays L.) submitted to different water conditions and dry matter estimation by energetic model. Revista Brasileira de Agrometeorologia, v.13, p.27-33, 2005.

NORMAN, J.M.; CAMPBELL, G.S. Canopy structure. In: PEARCY, R.W.; EHLEREINGER, J.R.; MOONEY, H.A.; RUNDEL, P.W. (Ed.). Plant physiological ecology: field methods and instrumentation. London: Chapman and Hall, 1989. p.301-325.

PENMAN, H.L. Natural evaporation from open water, bare soil and grass. Proceedings of the Royal Society of London. Series A, Mathematical and Physical Sciences, v.193, p.120-145, 1948.

SCOTT GREEN, D.; ERICKSON, J.E.; KRUGER, E.L. Foliar morphology and canopy nitrogen as predictors of light-use efficiency in terrestrial vegetation. Agricultural and Forest Meteorology, v.115, p.163-171, 2003.

SIVAKUMAR, M.V.K.; VIRMANI, S.M. Crop productivity in relation to interception of photosynthetically active radiation. Agricultural and Forest Meteorology, v.31, p.131-141, 1984.

THORPE, M.R. Net radiation and transpiration of apple trees in rows. Agricultural Meteorology, v.19, p.41-57, 1978.

VARLET-GRANCHER, C.; GOSSE, G.; CHARTIER, M.; SINOQUET, H.; BONHOME, R.; ALLIRAND, J.M. Mise au point: rayonnement solaire absorbé ou intercepté par un couvert végétal. Agronomie, v.9, p.419-439, 1989.

Received on September 24, 2010 and accepted on November 22, 2010 